\title{
Comparative study regarding the causes of land instability phenomena in the area of the Getic Subcarpathians
}

\author{
Constantin Rada ${ }^{1}$, Maria Lazăr $^{1}$, Florin Faur $^{1 *}$, and Izabela-Maria Apostu ${ }^{1}$ \\ ${ }^{1}$ University of Petrosani, Department of Environmental Engineering and Geology, University Street, \\ no. 20, Petrosani, Romania
}

\begin{abstract}
In Romania, as in many other countries of the world, there are areas, more or less extensive, which are naturally prone to landslides. Such an area, with great extension, is represented by the Getic Subcarpathians. In general, this predisposition of the mentioned area to landslides is favored by its geology and hydrogeology, its lithological structure, its morphology, the rainfall regime and to a lesser extent the tectonics of the region. Based on these considerations, in this paper, we have conducted a comparative study aimed at highlighting in a more concrete manner the causes that led to the onset of land instability phenomena recorded in the past 17 years in this area, also taking into account the human activities. For this purpose, we delimited three study areas, corresponding to the counties of Gorj (an area with shutdown mining activities), Vâlcea (area with lignite open-pits in operation) and Argeș (where human actions that can trigger landslides are related to infrastructure constructions, especially by excavation, other constructions, but also deforestation). This approach allows us to draw conclusions about the extent to which human activities amplify the frequency and intensity of land instability phenomena, and which of these activities has the most unfavorable influence.
\end{abstract}

\section{Introduction}

The phenomena of land instability (whether natural or modified by human activities) in the Subcarpathian area of Oltenia and Muntenia are relatively common, cause significant material damage, and, consequently, have attracted the attention of specialists over time.

The Getic Subcarpathians are framed from a morpho-structural point of view in the hilly floor with a high morpho-dynamic potential, where accentuated modeling processes and a great capacity of land degradation takes place [1]. It is an area where frequent landslides of progressive or regressive type occur, depending on the favorable factors, as well as subsidence or rock collapse phenomena [2,3]. The presence of landslides has been recorded over the years and is materialized through the presence of stabilized landslides and the existence of new or reactivated ones [1-4].

\footnotetext{
${ }^{*}$ Corresponding author: faurfloring@yahoo.com
} 
From this point of view, the studies and investigations undertaken overtime by different specialists show very clearly that the geological structure of the region is totally unfavorable to ensure the stability of the slopes [1,3].

The presence of the alternation of clayey-marly and clayey-dusty rocks with sandy or sandy-clayey formations or intercalations, with inclinations concordant with the inclination of the slopes and the existence of anticline or synclinal flanks on certain alignments, are structural elements that favored and favor the production of morpho-functional changes by landslides or subsidence $[1,3,5]$.

The contact surfaces between sandy and clayey formations or between diluvial formations and bedrock are the most favorable surfaces for landslides, especially in conditions of increased humidity or water saturation of sandy rocks, when colloidal or dusty clays tend to liquefy in the area of contact plans $[6,7]$.

In some of the investigated areas, where lignite reserves were identified, located in the Dacian deposits, that were/are extracted through open pit mining works, the natural predisposition to landslides of the terrains is amplified by the imbalances that appear in rock mass due to the extensive excavation works [2-5]. In turn, these imbalances associated with lignite extraction leads to the loss of the stability reserve of the excavated massif, especially when the designed elements stipulated by the technical projects for the exploitation programs are not strictly respected [3] (geometric elements, distance between machines, advance velocity and direction in the work fronts, etc.).

\section{Materials and methods}

In order to carry out the comparative study of the geostructural phenomena (especially landslides) produced in the area of the Getic Subcarpathians, under different conditions, three areas of interest were delimited:

- in the vicinity of the mining perimeters with shutdown activity - Poiana Seciuri Bustuchin (Gorj County);

- in the area of mining perimeters with current activity - Berbești - Alunu (Vâlcea County);

- in areas not influenced by mining activities, from Argeș County.

The aim of the study is to analyze in a comparative way the general stability of natural and artificial slopes, the causes and triggers of instability phenomena, the common conditions that led to their occurrence and to determine to what extent the study conclusions can be extrapolated on a larger scale, for the entire area of the Getic Subcarpathians (and possibly the Getic Plateau).

The history of landslides in the studied area shows a close connection between geological, hydrogeological, hydrometeorological and climatic factors and landslide phenomena. In some situations, the anthropogenic factor through mining, deforestation, constructions or even the biotic factor also intervenes (which, although it generally has positive effects on stability, there are situations, such as those identified in Argeș County, when old vegetation causes an overload which reduces the stability reserve of the terrain).

In order to achieve the proposed objectives, in a first phase, the landslides produced in the three studied areas were counted, being identified a series of characteristic elements (Table 1), after which a series of conclusions were drawn regarding the common causes which led to the triggering of landslides. 
Table 1. Centralized situation regarding landslides in the studied areas [8].

\begin{tabular}{|c|c|c|c|c|c|c|}
\hline \multirow[b]{2}{*}{ Description } & \multicolumn{6}{|c|}{ Investigated areas } \\
\hline & \multicolumn{2}{|c|}{$\begin{array}{l}\text { Poiana Seciuri - Bustuchin } \\
\text { (Gorj County) - shutdown } \\
\text { mining activities }\end{array}$} & \multicolumn{2}{|c|}{$\begin{array}{c}\text { Berbești - Alunu mining } \\
\text { perimeter (Vâlcea County) } \\
\text { - active open pit mining } \\
\text { (lignite) } \\
\end{array}$} & \multicolumn{2}{|c|}{$\begin{array}{c}\text { Arges County - areas } \\
\text { without mining activities }\end{array}$} \\
\hline $\mathbf{0}$ & \multicolumn{2}{|c|}{1} & \multicolumn{2}{|c|}{2} & \multicolumn{2}{|c|}{$\mathbf{3}$} \\
\hline Location & \multicolumn{2}{|c|}{$\begin{array}{l}\text { Amaradiei hills (part of } \\
\text { Getic Subcarpathians) }\end{array}$} & \multicolumn{2}{|c|}{ Getic Subcarpathians } & \multicolumn{2}{|c|}{$\begin{array}{l}\text { Includes almost all forms of } \\
\text { relief (including: Făgăraş } \\
\text { Mountains, } \\
\text { Subcarpathians, Getic Plateau, } \\
\text { Romanian Plain) }\end{array}$} \\
\hline Altitude & \multicolumn{2}{|c|}{ approx. $350 \mathrm{~m}$} & \multicolumn{2}{|l|}{$300-550 \mathrm{~m}$} & \multicolumn{2}{|c|}{$\begin{array}{l}160-2544 \mathrm{~m} \text { overall } \\
\text { In the area of the Getic } \\
\text { Subcarpathians and the Getic } \\
\text { Plateau the altitudes vary } \\
\text { between } 400-1218 \mathrm{~m}\end{array}$} \\
\hline $\begin{array}{l}\text { Nature of } \\
\text { the rocks }\end{array}$ & \multicolumn{2}{|c|}{$\begin{array}{l}\text { Clayey rocks (between } 33 \\
\text { and } 49 \% \text { ), clay-marly and } \\
\text { clay-dusty with sandy or } \\
\text { sandy-clay formations or } \\
\text { intercalations }\end{array}$} & \multicolumn{2}{|c|}{ Marly-clayey rocks and sands } & \multicolumn{2}{|c|}{$\begin{array}{l}\text { In the } \mathrm{N} \text { - crystalline mountain } \\
\text { units } \\
\text { In the N-E - Jurassic } \\
\text { (limestone, dolomite) and } \\
\text { Cretaceous (limestone, } \\
\text { conglomerate, sandstone) } \\
\text { formations } \\
\text { In the Getic Subcarpathians - } \\
\text { tertiary formations (limestone, } \\
\text { conglomerates, sandstones, } \\
\text { marls, sands, gravels) } \\
\text { In the Getic Piedmont and the } \\
\text { Romanian Plain - Levantine } \\
\text { and Quaternary-Pleistocene } \\
\text { formations on interfluves } \\
\text { (Cândeşti gravels) and } \\
\text { Holocene along the valleys and } \\
\text { on the plain (gravels, loess) }\end{array}$} \\
\hline $\begin{array}{l}\text { Surface and } \\
\text { ground } \\
\text { waters } \\
\end{array}$ & \multicolumn{2}{|c|}{$\begin{array}{l}\text { Amaradia River; aquifer } \\
\text { strata, horizons or lenses }\end{array}$} & \multicolumn{2}{|c|}{$\begin{array}{l}\text { Amaradia and Tărâia Rivers; } \\
\text { aquifer strata, horizons or } \\
\text { lenses }\end{array}$} & \multicolumn{2}{|c|}{$\begin{array}{l}\text { Rivers: Vedea, Topolog, } \\
\text { Arefu, Vâlsan etc.; aquifer } \\
\text { strata, horizons or lenses }\end{array}$} \\
\hline $\begin{array}{l}\text { Geodynamic } \\
\text { phenomena }\end{array}$ & \multicolumn{2}{|c|}{$\begin{array}{l}\text { Progressive or regressive } \\
\text { landslides, } \\
\text { settlement, subsidence and } \\
\text { rock collapses }\end{array}$} & \multicolumn{2}{|c|}{$\begin{array}{l}\text { Slope breaks, rock collapses } \\
\text { and landslides, erosion } \\
\text { phenomena (gullies, ravines) }\end{array}$} & \multicolumn{2}{|c|}{$\begin{array}{l}\text { Landslides, earth and debris } \\
\text { flows }\end{array}$} \\
\hline $\begin{array}{l}\text { Analyzed } \\
\text { period }\end{array}$ & \multicolumn{2}{|c|}{$2005-2019$} & \multicolumn{2}{|c|}{$2003-2020$} & \multicolumn{2}{|c|}{ 2005-2019 } \\
\hline \multirow{4}{*}{$\begin{array}{l}\text { Landslide } \\
\text { history }\end{array}$} & Data & Location & Data & Location & Data & Location \\
\hline & 20.07 .2005 & $\begin{array}{l}\text { Bustuchin } \\
\text { Commune }\end{array}$ & 21.01 .2003 & $\begin{array}{ll}\text { Valea } & \text { Mare } \\
\text { Village } & \end{array}$ & 14.04 .2006 & $\begin{array}{l}\text { Malureni } \\
\text { Commune ( } \\
\text { DC (Local } \\
\text { Road) 216) }\end{array}$ \\
\hline & 22.07 .2005 & $\begin{array}{l}\text { Bustuchin } \\
\text { Commune }\end{array}$ & $\begin{array}{l}10- \\
13.03 .2006\end{array}$ & $\begin{array}{l}\text { Valea Mare } \\
\text { Village } \\
\text { (Hamlets: } \\
\text { Amzulești, } \\
\text { Delureni, } \\
\text { Strâmba, } \\
\text { Păsărei and } \\
\text { Roșioara) }\end{array}$ & 12.01 .2007 & $\begin{array}{l}\text { Curtea de Argeș } \\
\text { City, } \\
\text { (Vișina Street) }\end{array}$ \\
\hline & 23.08 .2005 & $\begin{array}{l}\text { Bustuchin } \\
\text { Commune }\end{array}$ & $\begin{array}{l}05- \\
09.02 .2008\end{array}$ & $\begin{array}{l}\text { North Panga } \\
\text { exterior waste } \\
\text { dump; Turcești } \\
\text { Village }\end{array}$ & $\begin{array}{l}15.02- \\
23.03 .2007\end{array}$ & $\begin{array}{l}\text { DJ } 731 \text { Corbi - } \\
\text { Nucșoara; DJ } \\
732 \text { C Godeni - } \\
\text { Lăzărești; Capu } \\
\text { Piscului Village }\end{array}$ \\
\hline
\end{tabular}




\begin{tabular}{|c|c|c|c|c|c|c|}
\hline $\mathbf{0}$ & \multicolumn{2}{|r|}{1} & \multicolumn{2}{|r|}{2} & \multicolumn{2}{|r|}{3} \\
\hline & 13.09 .2005 & $\begin{array}{l}\text { Bustuchin } \\
\text { Commune }\end{array}$ & 26.12 .2009 & $\begin{array}{l}\text { Făurești, } \\
\text { Diulești, Valea } \\
\text { Mare, Bălcești, } \\
\text { Giulești } \\
\text { Villages }\end{array}$ & 09.01 .2008 & $\begin{array}{l}\text { DN (National } \\
\text { Road) } 73 \mathrm{C} \text {; } \\
\text { Ciofrângeni } \\
\text { Commune }\end{array}$ \\
\hline & 26.10 .2005 & $\begin{array}{l}\text { Bustuchin and } \\
\text { Poiana Seciuri } \\
\text { Villages }\end{array}$ & 16.01 .2010 & $\begin{array}{l}\text { Berbeşti } \\
\text { Village }\end{array}$ & 19.08.2008 & $\begin{array}{l}\text { Valea Danului } \\
\text { Commune (DC } \\
\text { 243) }\end{array}$ \\
\hline & 06.02 .2006 & $\begin{array}{l}\text { Poieniţa, } \\
\text { Poiana } \\
\text { Seciuri, Valea } \\
\text { Pojarului and } \\
\text { Bustuchin } \\
\text { Villages } \\
\end{array}$ & 05.03 .2010 & $\begin{array}{l}\text { South Panga } \\
\text { waste dump }\end{array}$ & 11.02 .2009 & $\begin{array}{lr}\text { DJ } & 735 \\
\text { Campulung } & - \\
\text { Albești } & - \\
\text { Cândești }\end{array}$ \\
\hline & 20.04 .2006 & $\begin{array}{l}\text { Bustuchin } \\
\text { Commune }\end{array}$ & 07.03 .2010 & $\begin{array}{l}\text { the southern } \\
\text { part of the } \\
\text { Berbești - } \\
\text { Alunu mining } \\
\text { perimeter }\end{array}$ & 16.07.2009 & $\begin{array}{l}\text { Uda, Babana, } \\
\text { Arefu } \\
\text { Communes; DC } \\
187\end{array}$ \\
\hline & 14.05 .2006 & $\begin{array}{l}\text { Poieniţa, } \\
\text { Poiana } \\
\text { Seciuri, } \\
\text { Cionți and } \\
\text { Bustuchin } \\
\text { Villages } \\
\end{array}$ & 22.06 .2010 & $\begin{array}{l}\text { North-east side } \\
\text { of Panga open } \\
\text { pit }\end{array}$ & 24.02 .2010 & $\begin{array}{l}\text { Boteni } \\
\text { Commune }\end{array}$ \\
\hline & 03.07.2007 & $\begin{array}{l}\text { Nămete, } \\
\text { Cionți, } \\
\text { Motorgi, } \\
\text { Poiana Seciuri } \\
\text { and Bustuchin } \\
\text { Villages } \\
\end{array}$ & 02.07.2010 & $\begin{array}{l}\text { North side of } \\
\text { Panga open pit }\end{array}$ & 08.04 .2010 & $\begin{array}{lr}\text { Curtea de Arges } \\
\text { City } & \text { (Plopiş } \\
\text { Street) } & \end{array}$ \\
\hline & 18.09.2007 & $\begin{array}{l}\text { Poiana } \\
\text { Seciuri, } \\
\text { Poieniţa, } \\
\text { Bustuchin and } \\
\text { Valea } \\
\text { Pojarului } \\
\text { Villages }\end{array}$ & 06.09 .2010 & $\begin{array}{l}\text { South side of } \\
\text { Panga open pit }\end{array}$ & 14.02 .2011 & $\begin{array}{l}\text { Uda Commune, } \\
\text { DJ 703B }\end{array}$ \\
\hline & 05.04 .2013 & $\begin{array}{l}\text { Roșia de } \\
\text { Amaradia and } \\
\text { Bustuchin } \\
\text { Communes; } \\
\text { DJ (County } \\
\text { Road) 675 C } \\
\end{array}$ & 22.11 .2010 & $\begin{array}{l}\text { South side of } \\
\text { Panga open } \\
\text { pit; Valea } \\
\text { Mare Village }\end{array}$ & 17.02.2011 & $\begin{array}{ll}\begin{array}{l}\text { Poienari } \\
\text { Muscel }\end{array} & \text { de } \\
\text { Commune, } & \text { DJ } \\
738 & \end{array}$ \\
\hline & 12.04 .2013 & $\begin{array}{l}\text { Poiana Seciuri } \\
\text { Village }\end{array}$ & 29.11 .2010 & $\begin{array}{l}\text { Northern slope } \\
\text { of Panga open } \\
\text { pit }\end{array}$ & 11.01 .2012 & $\begin{array}{l}\text { Arefu } \\
\text { Commune }\end{array}$ \\
\hline & 17.02 .2014 & $\begin{array}{l}\text { Ruget, } \\
\text { Negomir, } \\
\text { Stejaruşi } \\
\text { Villages; } \\
\text { Seciuri former } \\
\text { open pit } \\
\end{array}$ & 07.02 .2011 & $\begin{array}{l}\text { North side of } \\
\text { Panga open } \\
\text { pit; Valea } \\
\text { Mare Village } \\
\text { (Amzuleşti } \\
\text { Hamlet) } \\
\end{array}$ & 12.06 .2012 & $\begin{array}{l}\text { Arefu } \\
\text { Commune }\end{array}$ \\
\hline & 07.03 .2014 & $\begin{array}{l}\text { Roşia de } \\
\text { Amaradia and } \\
\text { Bustuchin } \\
\text { Communes }\end{array}$ & 15.11 .2011 & $\begin{array}{l}\text { North side of } \\
\text { Panga open pit }\end{array}$ & 03.04 .2013 & $\begin{array}{l}\text { Ciofrângeni, } \\
\text { Şuici, } \\
\text { Cotmeana, } \\
\text { Corbi, Cepari, } \\
\text { Communes }\end{array}$ \\
\hline & 10.12 .2014 & $\begin{array}{l}\text { Roşia de } \\
\text { Amaradia } \\
\text { Commune; } \\
\text { Ruget Village } \\
\end{array}$ & 19.02.2012 & $\begin{array}{l}\text { Northern slope } \\
\text { of Panga open } \\
\text { pit }\end{array}$ & 11.06 .2013 & Cocu Commune \\
\hline
\end{tabular}




\begin{tabular}{|c|c|c|c|c|c|c|}
\hline $\mathbf{0}$ & \multicolumn{2}{|r|}{1} & \multicolumn{2}{|r|}{2} & \multicolumn{2}{|r|}{3} \\
\hline & \multirow[t]{13}{*}{28.02 .2019} & \multirow[t]{13}{*}{$\begin{array}{l}\text { Amaradia } \\
\text { River }\end{array}$} & 07.04 .2012 & \multirow{2}{*}{ 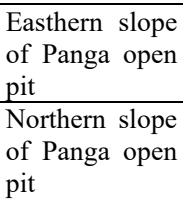 } & 03.05 .2014 & $\begin{array}{l}\text { Curtea de Argeș } \\
\text { City (Rm. } \\
\text { Vâlcea Street) }\end{array}$ \\
\hline & & & 01.06 .2012 & & 06.05 .2014 & $\begin{array}{l}\text { Piatra Village, } \\
\text { DN 73C }\end{array}$ \\
\hline & & & 05.06 .2012 & $\begin{array}{l}\text { Easthern slope } \\
\text { of Panga open } \\
\text { pit }\end{array}$ & 23.09 .2014 & $\begin{array}{l}\text { Băiculești } \\
\text { Commune }\end{array}$ \\
\hline & & & 10.12.2012 & $\begin{array}{l}\text { Northern slope } \\
\text { of Panga open } \\
\text { pit }\end{array}$ & 26.09 .2015 & $\begin{array}{l}\text { Vernești and } \\
\text { Borobenești } \\
\text { Villages }\end{array}$ \\
\hline & & & $\begin{array}{l}15- \\
16.03 .2013\end{array}$ & $\begin{array}{l}\text { Easthern slope } \\
\text { of Panga open } \\
\text { pit }\end{array}$ & 16.03 .2017 & $\begin{array}{l}\text { DN } 73 \mathrm{C} \\
\text { between Curtea } \\
\text { de Argeş and } \\
\text { Burluşi }\end{array}$ \\
\hline & & & 27.02 .2014 & $\begin{array}{l}\text { Northern slope } \\
\text { of Panga open } \\
\text { pit }\end{array}$ & 19.07.2018 & $\begin{array}{l}\text { Muscel } \\
\text { Commun; DJ } \\
738 \\
\text { (Câmpulung - } \\
\text { Pitești and } \\
\text { Câmpulung - } \\
\text { Curtea } \\
\text { Argeš); de } \\
\text { Mihăeşti } \\
\text { Commune } \\
\text { (Draghici } \\
\text { Village }\end{array}$ \\
\hline & & & 29.07.2014 & $\begin{array}{l}\text { Northern slope } \\
\text { of Panga open } \\
\text { pit }\end{array}$ & 03.08 .2018 & $\begin{array}{ll}\mathrm{DN} & 73 \mathrm{D} \\
\text { between } & \\
\text { Mioveni } & \text { and } \\
\text { Stoenești } & \\
\end{array}$ \\
\hline & & & 21.08 .2015 & Panga open pit & 07.08 .2018 & $\begin{array}{l}\text { DN 7, Drăganu } \\
\text { Commune }\end{array}$ \\
\hline & & & 18.09 .2015 & $\begin{array}{l}\text { North side of } \\
\text { Panga open pit }\end{array}$ & 01.06 .2019 & $\begin{array}{l}\text { DN73D, Boteni } \\
\text { Commune }\end{array}$ \\
\hline & & & 11.03 .2016 & $\begin{array}{l}\text { North side of } \\
\text { Panga open pit }\end{array}$ & 02.06 .2019 & $\begin{array}{l}\text { DN73D, Boteni } \\
\text { Commune }\end{array}$ \\
\hline & & & 10.05 .2017 & $\begin{array}{l}\text { Alunu exterior } \\
\text { waste dump } \\
\text { DJ } 605 \\
\text { Berbești-Alunu }\end{array}$ & & \\
\hline & & & 23.05 .2019 & Alunu open pit & & \\
\hline & & & 14.01 .2020 & Alunu open pit & & \\
\hline Causes & $\begin{array}{l}\text { Natural: } \\
\text { structure, i } \\
\text { rock layer } \\
\text { with the it } \\
\text { slopes, } \\
\text { precipitatio } \\
\text { increase of } \\
\text { level and } \\
\text { the water } \\
\text { rock pores } \\
\text { floods on } \\
\text { River, wh } \\
\text { appearance } \\
\text { phenomena } \\
\text { the slopes } \\
\text { thawing ph }\end{array}$ & $\begin{array}{r}\text { geological } \\
\text { clination of the } \\
\text { in accordance } \\
\text { clination of the } \\
\text { intensive } \\
\text { is that led to the } \\
\text { he groundwater } \\
\text { nanifestation of } \\
\text { pressure in the } \\
\text { nd formation of } \\
\text { the Amaradia } \\
\text { ch led to the } \\
\text { of erosion } \\
\text { at the base of } \\
\text { the freezing- } \\
\text { nomena }\end{array}$ & $\begin{array}{l}\text { Natural: gec } \\
\text { of the are } \\
\text { rainfall } \\
\text { Anthropoger } \\
\text { activities }\end{array}$ & $\begin{array}{lr}\text { logical } & \text { structure } \\
\text { and } & \text { intensive } \\
\text { ic: } & \text { mining }\end{array}$ & $\begin{array}{l}\text { Natural: geo } \\
\text { the area and } \\
\text { Anthropoger } \\
\text { construction } \\
\text { decrease of } \\
\text { certain areas } \\
\text { works to } \\
\text { moisture; lar } \\
\text { are spread } \\
\text { entire count } \\
\text { were origin } \\
\text { imbalance } \\
\text { activities }\end{array}$ & $\begin{array}{l}\text { ogical structure of } \\
\text { intensive rainfall } \\
\text { ic: ro road } \\
\text { activities, } \\
\text { the forest fund in } \\
\text { lack of specific } \\
\text { eliminate excess } \\
\text { dslide-prone areas } \\
\text { over almost the } \\
\text {, many landslides } \\
\text { illy caused by an } \\
\text { aused by human }\end{array}$ \\
\hline
\end{tabular}




\begin{tabular}{|c|c|c|c|}
\hline $\mathbf{0}$ & 1 & 2 & 3 \\
\hline $\begin{array}{l}\text { Triggering } \\
\text { factors }\end{array}$ & $\begin{array}{l}\text { Geological structure of the } \\
\text { region and the nature of the } \\
\text { rocks } \\
\text { Presence of aquifer } \\
\text { formations } \\
\text { Erosive action of Amaradia } \\
\text { River or torrents formed by } \\
\text { heavy rainfall } \\
\text { The anthropogenic factor: } \\
\text { crude oil and natural gas } \\
\text { extraction activities, } \\
\text { exploitation of deposits of } \\
\text { useful mineral substances, } \\
\text { heavy traffic, constructions, } \\
\text { etc. } \\
\text { The biotic factor has } \\
\text { negative effects through } \\
\text { deforestation, lack of } \\
\text { afforestation works, the } \\
\text { existence of an aging } \\
\text { vegetation }\end{array}$ & $\begin{array}{l}\text { Geometric elements of } \\
\text { working and dumping slopes, } \\
\text { inadequate dumping } \\
\text { technologies (upstream to } \\
\text { downstream deposition) and } \\
\text { excavation technologies (at } \\
\text { the base of the step) } \\
\text { Presence of cracks, fissures } \\
\text { and faults in the lignite } \\
\text { mining area } \\
\text { Phenomena of rain erosion } \\
\text { The variation of the rock } \\
\text { humidity, the manifestation } \\
\text { of the water pressure in the } \\
\text { pores, the manifestation of } \\
\text { the hydrodynamic pressure, } \\
\text { the stagnation of the water on } \\
\text { the dump or at the base of the } \\
\text { slopes (in the twinning areas } \\
\text { of the dump with the natural } \\
\text { slopes) } \\
\text { Vibrations caused by heavy } \\
\text { machinery }\end{array}$ & $\begin{array}{l}\text { Climatic and meteorological } \\
\text { factors: precipitation, freezing- } \\
\text { thawing phenomena, drought, } \\
\text { etc. } \\
\text { Variation of rock moisture, } \\
\text { manifestation of water } \\
\text { pressure in the pores, } \\
\text { manifestation of hydrodynamic } \\
\text { pressure }\end{array}$ \\
\hline Effects & \multicolumn{3}{|c|}{$\begin{array}{l}\text { Destruction of households, communication networks, municipal networks, open pit } \\
\text { equipments*, geo-structural changes, etc. }\end{array}$} \\
\hline Measures & $\begin{array}{l}\text { Sheltering the population } \\
\text { Relocation of the population } \\
\text { whose houses were } \\
\text { completely destroyed } \\
\text { Stiffening of foundations } \\
\text { and cracks in houses that } \\
\text { have been slightly affected } \\
\text { Improving the stability of } \\
\text { slopes by geometric, } \\
\text { hydrological, biological and } \\
\text { mechanical methods }\end{array}$ & $\begin{array}{l}\text { Evacuation of the endangered } \\
\text { population } \\
\text { Withdrawal of mining } \\
\text { equipment } \\
\text { Landslide monitoring } \\
\text { Improving the stability of } \\
\text { slopes by geometric, } \\
\text { hydrological, biological and } \\
\text { mechanical methods } \\
\text { (leveling, compaction, } \\
\text { achieving an appropriate } \\
\text { inclination for water drainage } \\
\text { from platforms and berms, } \\
\text { terracing, construction of } \\
\text { rock spurs, etc.) } \\
\text { Removal of slippery earth } \\
\text { masses and opening of new } \\
\text { work fronts in areas not } \\
\text { affected by landslides }\end{array}$ & $\begin{array}{l}\text { Evacuation of the endangered } \\
\text { population } \\
\text { Improving slope stability } \\
\text { Drainage of surface and } \\
\text { groundwater } \\
\text { Development of reverse filters } \\
\text { to reduce the effect of } \\
\text { suffosion } \\
\text { Grassing, revegetation } \\
\text { Resistance works (retaining } \\
\text { walls, piles, caissons, bars, } \\
\text { molded walls, etc.) }\end{array}$ \\
\hline
\end{tabular}

*valid only for the areas with active mining activities (Berbești - Alunu mining perimeter in Vâlcea County)

To support those presented in Table 1, we further present a series of photographs illustrating the landslides produced over time and their effects on the various anthropogenic objectives in the three studied areas (Fig. 1-4).
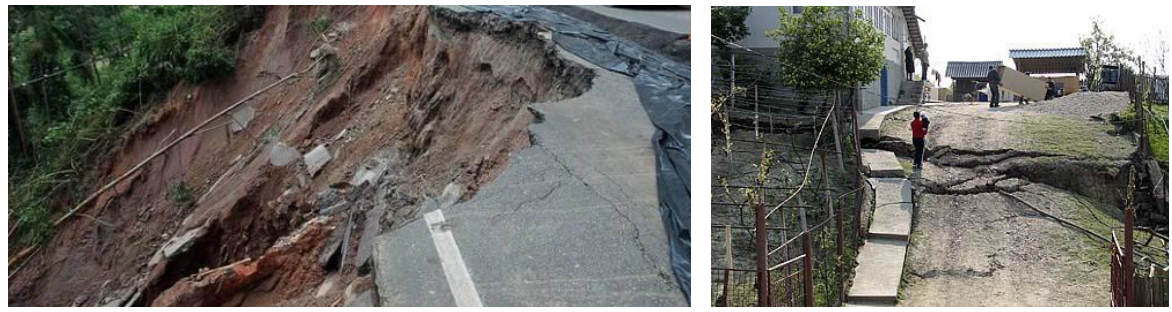

Fig. 1. Landslides and their effects in Poiana Seciuri - Bustuchin area (Gorj County). 

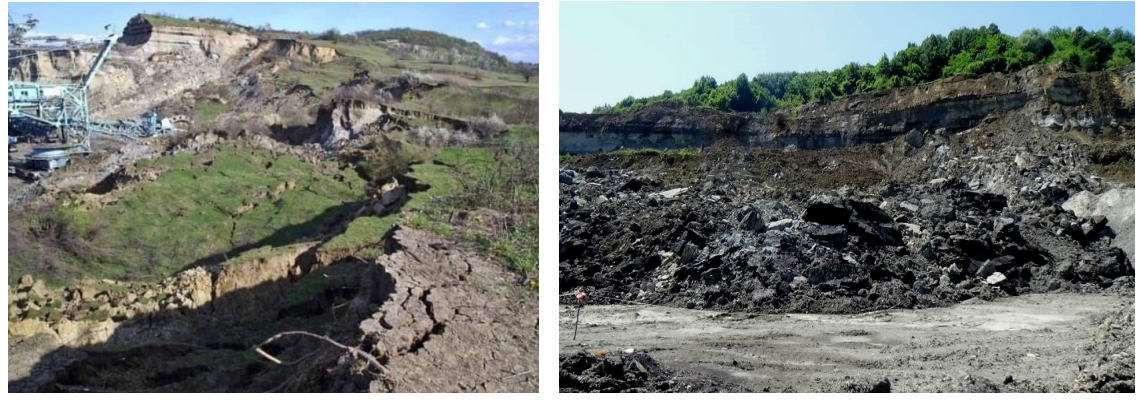

Fig. 2. Massive landslides affecting mining operations in Panga and Alunu open pits (Vâlcea County).
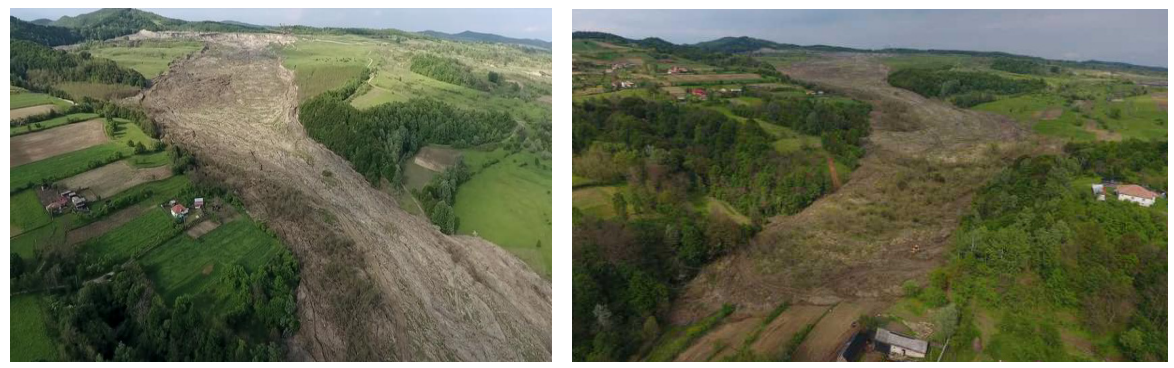

Fig. 3. Massive slide of Alunu exterior waste dump (left - in 2017; right - in 2019 partially stabilized and revegetated).
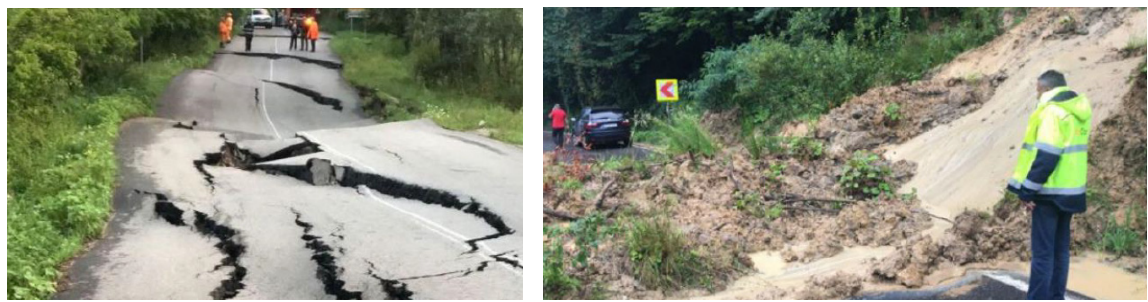

Fig. 4. Landslides in Argeș County and their effects on infrastructures.

Starting from those presented in Table 1, and taking into account previous studies conducted in the studied areas, we can analyze in a relatively unitary way the general causes and specific triggers of landslides recorded in the last 17 years.

\section{Results and discussions}

The area with shutdown mining activity, Poiana Seciuri-Bustuchin (Gorj County), and the area with mining activity in operation, Berbești - Alunu mining perimeter (Vâlcea County), are located entirely in the region of the Getic Subcarpathians, while the studied area from Argeș County extends from north to south and includes almost all forms of relief, from mountains to plains (the study took into account especially the region of the Getic Subcarpathians, including parts of the Getic Plateau).

The history of landslides over a period of about 17 years was analyzed and it was found that many such medium and large phenomena occurred, with significant negative effects. These include: partial or total destruction of households (fissures or even cracks, having widths of a few $\mathrm{cm}$ or tens of $\mathrm{cm}$ and extended over the entire height of the walls of houses), covering access roads with sliding material, destruction of access roads (cracks 
with depths of the order of meters), destruction of bridges and footbridges, destruction of open pit working equipments, etc.

The effects of landslides were felt most strongly in areas outside the mining perimeters, as they directly affected the population by destroying buildings of any kind. Stronger effects were also felt in the regions where mining activities are active.

Most landslides occurred, during the studied period, in the Berbești - Alunu mining perimeter, in Panga and Alunu open pits and in the adjacent areas, including some nearby villages. It is mentioned that most of the landslides occurred at the working slopes of the open pits, respectively at the slopes of the inner and outer dumps (belonging to the two mentioned open pits) $[8,9]$.

If we refer to the analyzed surface, it is observed that in Argeș County we distinguish small landslide phenomena, located and generally stabilized, unlike the areas where open pit mining operations have operated or are operating.

Reactivations of landslides were registered especially in the case of the Poiana SeciuriBustuchin area (area with shutdown mining activity) and the Berbești - Alunu mining perimeter (area with active mining activities) and to a lesser extent in the studied areas from Argeș County.

It is found that most landslides occurred during periods of heavy rainfall, in spring or autumn or as a result of snow melting.

In the Getic Subcarpathians and Getic Plateau, the annual precipitations fall is between 500 and $700 \mathrm{~mm}$, the values being higher in the north of the Getic Plateau and in the case of the Subcarpathian hilly units. The annual maximum of precipitations is registered in MayJune, and the annual minimum of precipitations is registered in the winter months, in January and February, when at the level of the entire country an anticyclonic circulation dominates. There are also frequent deviations from this regime. Thus, sometimes, the maximum precipitation occurs in another months (July or August), and so does the annual minimum. In certain areas and regions of Romania, the annual regime is characterized by two maxima, respectively two minima, these cases being also found in the region of the Getic Subcarpathians. Thus, the main maximum of precipitation is doubled by a second secondary maximum, which is achieved in late autumn and early winter. The second secondary minimum of precipitation occurs in the months of late summer and early autumn (August and September) [10].

In winter months and especially in February there were landslides which are explained either by melting snow or by falling liquid precipitation instead of solid ones due to the sub-mountain altitudes (or by combining the two factors), which in the analyzed area varies between 300 and $1218 \mathrm{~m}$, the southern exposure and the milder climate.

In summer months, in June and July, significant precipitation amounts fell in the Getic Subcarpathians in short periods of time (high intensity rainfall), sometimes leading to landslides (such as the landslides from 2019) [3].

Excessive water intake from precipitation or melting snow has led to an increase in the amount of water infiltrated into the soil and subsoil. The increase of moisture caused the decrease of rocks resistance, the increase of their volumetric weight, the manifestation of water pressure in the pores and of hydrodynamic pressure, all having an unfavorable influence on the stability of the natural and/or artificial slopes [11].

After dry periods, following the contraction of the lands, cracks and fissures are formed, which constitute additional ways of water penetration on their trajectory. This situation is unfavorable when precipitation begins to fall, as water infiltrates through the formed cracks and these can later become surfaces of detachment or sliding of rock masses [6].

Looking at the link between landslides the hydrometeorological and climatic conditions, one of the main factors that determine the precipitation regime is mentioned, namely the 
distance from the place of precipitation. Thus, the amount of precipitation decreases as the distance from the place of precipitation increases.

The Getic Subcarpathians consist almost entirely of Pliocene and Miocene deposits, represented by an alternation of clays, sandstones, clayey sandstones, marls, conglomerates, gypsum, sands, etc., with the lowest tectonization in the entire Subcarpathian unit. The presence of Oligocene deposits, typical of the Carpathians, in the formation of peaks that penetrate the Subcarpathians, or as insular appearances in the axis of some Subcarpathian anticline peaks is accidental [12].

Analyzing the history of landslides, it is observed that there were none produced simultaneously in the three studied areas, leading us to the conclusion that landslides depend especially by local conditions (morphology, geology, hydrogeology etc.), the only common triggering factor being represented by water (precipitations, snow melt or both).

\section{Conclusions}

Summarizing those presented in this study, some general conclusions can be drawn valid for the entire area of the Getic Subcarpathians:

- the three studied areas are part of the same relief unit: the Getic Subcarpathians, with the mention that for Argeș County the landslide phenomena registered in lower relief units, such as the Getic Plateau, were also taken into account;

- in the lithological composition of the Getic Subcarpathians, Pliocene and Miocene deposits predominate, represented by an alternation of clays, sandstones, clayey sandstones, marls, conglomerates, gypsum, sands, etc. These represent common conditions to the three studied areas, the only differences being represented by the arrangement of the mentioned rock layers, their thickness, their inclination in relation to the inclination of the slopes, etc. The artificial earth constructions, represented by mining waste dumps, consist of a heterogeneous mixture of sedimentary rocks (clays, marls, powders, sands etc.) that originate from the natural formations excavated in the lignite mining process;

- heavy rainfall and snow melting are the main cause for the occurrence of geostructural phenomena due to the fact that water infiltrates into the soil and subsoil causing a worsening of rocks strength characteristics, an increase of their volumetric weight, the appearance of pore water and hydrodynamic pressures, and, in the existing lithological conditions, have an unfavorable influence on the stability of the natural and/or artificial slopes;

- open pit mining (and sometimes former underground mining activities) influences the number and intensity of geostructural phenomena more than other anthropogenic interventions (constructions, infrastructure, etc.) and involves the entrainment of much larger volumes of rocks;

- the reactivation of landslides is manifested mainly in the areas of mining perimeters (with shutdown or current activities - in Gorj and Vâlcea Counties), while in Argeș County their reactivation is sporadic, it manifests itself on small areas and involves much smaller volumes of material.

The absence of stability improvement engineering works, which can be performed by geometric methods (design of favorable geometric elements, respectively lower heights or angles), hydrological and hydrogeological (rainwater drainage, groundwater drainage and aquifers dewatering, reverse filters to reduce the effect of suffosion, etc.), biological (grassing, afforestation) and mechanical (leveling, compaction, achieving an appropriate inclination to drain water from platforms and berms, terracing, construction of rock spurs, construction of retaining walls, caissons, barrettes, molded walls, covering the slopes with wire nets, etc.) caused the repeated manifestation of landslides and other geostructural phenomena that affected households and road infrastructure of local or national importance. 
Given that the listed measures were not applied, especially because they involved significant financial resources or for other reasons, the authorities often resorted to the measure of relocation of the population at risk, with significant negative implications in socio-human terms.

\section{References}

1. R.M. Maftei, C. Filipciuc, G. Vina, Environmental Engineering and Management Journal, 11 (12), 2223-2232 (2012)

2. R.V. Chiriță, M. Lazăr, F. Faur, Annals of the University of Petroşani, Mining Engineering, 19, 132-145 (2018)

3. M. Lazăr, F. Faur, I. Rotunjanu, C. Rada, I.M. Apostu, Annals of the University of Petroşani, Mining Engineering, 21, 86-99 (2020)

4. D. Fodor, N. Dican, Mining Revue, 19 (2), 2-11 (2013)

5. D. Fodor, N. Dican, Mining Revue, 19 (3), 2-9 (2013)

6. I. Rotunjanu, Stabilitatea taluzurilor și versanților (Natural and artificial slope stability) (Infomin, Deva, 2005)

7. C.W. Duncan, W.M. Christopher, Rock Slope Engineering. Civil and mining, 4th edition (Spon Press - Taylor \& Francis Group, New York, 2005)

8. C. Rada, Identification of the causes and triggering factors of landslides and measures to combat and prevent them (in Romanian), Scientific Research Report No. 2, Petrosani (2020)

9. R.V. Chiriță, Research on geomorphological changes generated by mining activities in the Berbesti mining basin and their impact on the environment (in Romanian), Doctoral thesis, Petroșani (2019)

10 M. Ielenicz, I.G. Pătru, Geografia fizică a României (Physical geography of Romania) (Universitară, Bucharest, 2011)

11 C. Rada, F. Faur, MATEC Web of Conferences, 290, 11010 (2019)

12. C. Brânduş, Revista de Geomorfologie, tomul I (1997) 